\title{
SOIL SUITABILITY ESTIMATION FOR HOUSING PURPOSES IN LANDSLIDE-PRONE AREAS. THE CASE OF KARYA VILLAGE, PATRAS, W. GREECE
}

\author{
Koukis G. ${ }^{1}$, Sabatakakis N. ${ }^{1}$, and Lainas S. ${ }^{1}$ \\ ${ }^{\prime}$ University of Patras, Department of Geology, Section of Applied Geology and Geophysics, \\ Laboratory of Engineering Geology,g.koukis@upatras.gr, \\ sabatak@upatras.gr,splainas@upatras.gr
}

\begin{abstract}
This paper discusses a method of soil suitability estimation for housing purposes in landslide-prone areas based on engineering geological criteria. The studied places, Karya and Neo Souli villages are located on the eastern part of the city of Patras. Several instability problems were identified triggered by heavy rainfalls, especially during extreme meteorological events. The soil formations were classified in several geotechnical units while typical geotechnical profiles and slip sections were drawn. Limit equilibrium slope stability analyses were established in order to investigate the critical slide conditions, using shear strength parameters estimated from laboratory and in-situ testing. The studied area was finally divided into five zones according to the suitability of the encountered ground regarding housing purposes.
\end{abstract}

Key words: Geotechnical Survey, Slope Stability analysis, Soil Suitability, Western Greece.

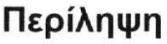

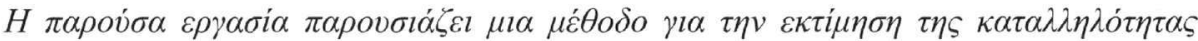

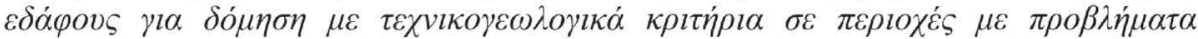

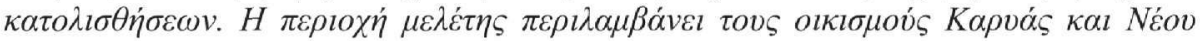

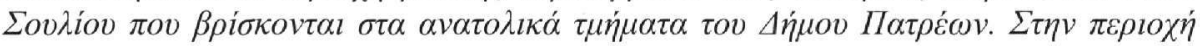

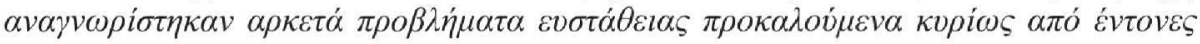

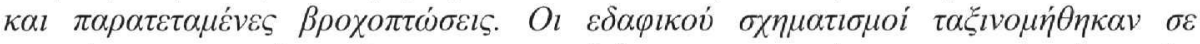

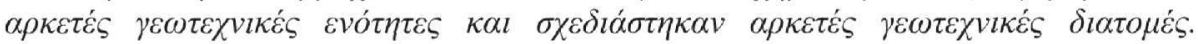

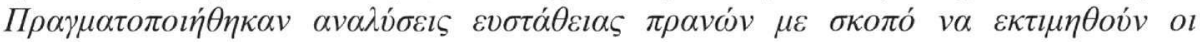

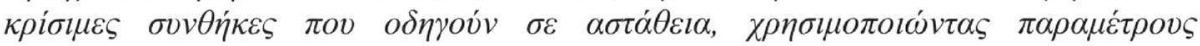

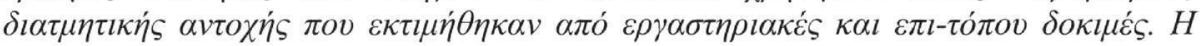

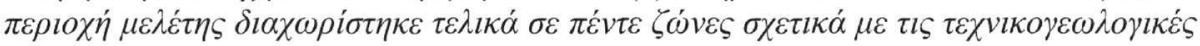

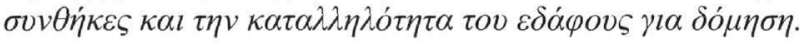

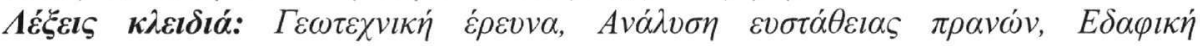
$\kappa \alpha \tau \alpha \lambda \lambda \eta \lambda \dot{\tau} \tau \eta \tau \alpha, \Delta v \tau \imath \kappa \dot{~ E \lambda \lambda \alpha ́ \delta \alpha . ~}$ 


\section{Introduction}

The evaluation of soil suitability for housing purposes is very important for urban planning. A detailed engineering geological and geotechnical appraisal provides all the essential information regarding the engineering geological and geotechnical environment leading to a ground zonation for housing purposes.

In Greece, a trend of urban expansion is taking place during the last years. Unfortunately, rapid construction by ignoring the engineering geological and geotechnical environment has resulted in some cases to slope instability phenomena and damages of properties and infrastructures. In such cases, factors such as variant lithological composition, strong folding and high relief energy favor the manifestation of such phenomena mainly triggered by heavy rainfalls and earthquakes. The interrelation between landslides and precipitation in western Greece was first established by Koukis et al. (1996). They analysed precipitation data from thirty gauging stations, covering a period of more than 27 years (1953 to 1991), in combination with data recordings through a database of landslide phenomena for the same time period.

The large landslide events of 1999 and 2001 in Karya village during a period of intense rainfall (Sabatakakis et al. 2005) made Local Authorities to focus their attention on evaluating soil suitability for housing purposes. To aid the planning the Department of Geology of Patras University was commissioned to undertake a geotechnical appraisal. An extensive program of geological and geotechnical investigations was carried out in order to find the causes of instability, design remedial measures and draw useful conclusions for future urban design.

\section{Physiografic and geological setting}

\subsection{Location and morphological characteristics}

The study area, involving Karya and N. Souli villages, belongs to Municipality of Patras, is located about $12 \mathrm{Km}$ away from the city center (Fig. 1) and sited close to the edge of Panahaikon mountain range at $350 \mathrm{~m}$ a.s.l. The general morphology of the area depends strongly on the lithological and structural characteristics of bedrock formations. Many hillslopes are steep, with varying inclinations, sometimes exceeding $35 \%$, reflecting bedrock composition and structure. Steeper slopes are located near the eastern boundaries of Karya village where Olonos - Pindos bebrock formations outcrop. On the other hand area of N. Souli village is relatively flat, without significant instability problems. Drainage regime has a general W-E direction and it is mainly characterized by Glafkos River. It is the main stream channel in the broader region and flows throughout the year.

Although the inclination of affected slopes in Karya village does not exceed $20^{\circ}$ the area shows unstable slopes, due to intense past tectonic action combined with continuous weathering and erosion. This is mostly exemplified by the transversal flow streams that create deep gullies with steep slopes.

\subsection{Geological setting and engineering geological conditions}

Local geology is relatively complex involving the features of Olonos - Pindos alpine basement and Pleistocene-Holocene deposits. Bedrock formations are characterized by intense thrusting, folding and fracturing resulting from the intense tectonism of the zone. ENE and WNW directed high angle normal faults were recognized following the rhomboid pattern in Patras area (Doutsos and Kokkalas 2001, Koukouvelas and Doutsos 1996, Zelilidis et al. 1988, Ferentinos et al. 1985). 


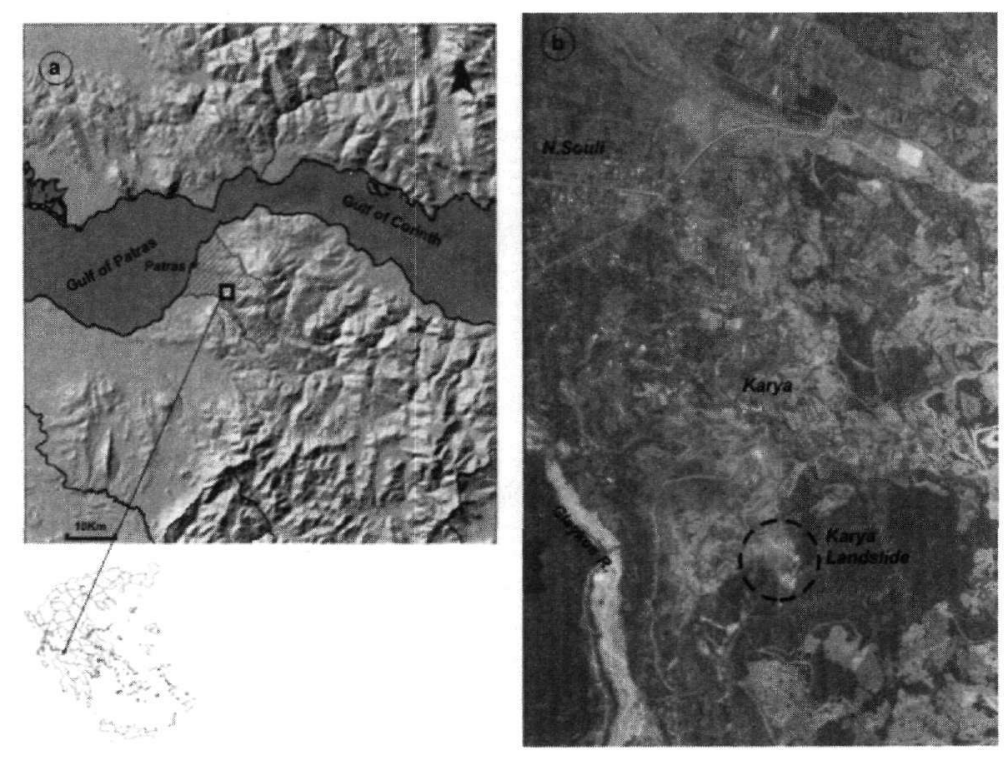

Figure 1 - (a) location, (b) aerial photo (captured in 1994)

The various formations encountered were classified into ten engineering geological units according to their relative age and physical characteristics. The lower part of the normal sedimentary sequence includes schists and cherts of Jurassic age, which are covered by thin bedded Cretaceous limestones. A transition zone is developed above the limestones including limestones, shales, scherts and marls, leading to the typical flysch sediments. Clastic deposits including scree and debris overlay bedrock materials. The hillslopes around Karya village consist mainly of scree and transition zone intensely fractured materials, whereas in N. Souli downslope area feature Pleistocene and Holocene deposits. Cherts and limestones typically outcrop at the mountaneous area near the SE margins of Karya village (Fig. 2).

The natural slopes formed by tectonic activity have been subjected to a continuous process of degradation, favored by wet climate. Water action is considered to be the most important factor involved in the degradation process contributing to slope failure mechanisms. Water action combined with the poor mechanical characteristics of the surfacial materials leads to strength reduction and subsequent multi-scale instability problems triggered by heavy rainfalls and favored by human activities.

\section{Instability phenomena}

The engineering geological conditions of the encountered formations combined with extreme meterorogical events favor the manifestation of slope instability phenomena. Several instability phenomena and landslide- prone areas where recognized. The most serious instability phenomena are focused in Karya Landslide area (Fig. 3). This landslide has been investigated in detail by the Laboratory of Engineering Geology, University of Patras (Koukis 2003) and several remedial works have been proposed to stabilize the area. According to Sabatakakis et al. (2005), it comprises an extensive instability zones of periodically induced landlide events interspersed with creep activity.

The first significant failure was recorded in 1962, a year with almost the double annual precipitation records than the previous year, and resulted to the partial destruction of old Karya village which was founded on the head of the landslide. The landslide reactivated in February 1999, where a sudden mass movement occurred during an intense and prolonged rainfall. According to precipitation data recorded by the gauging station of Patras the February's 1999 


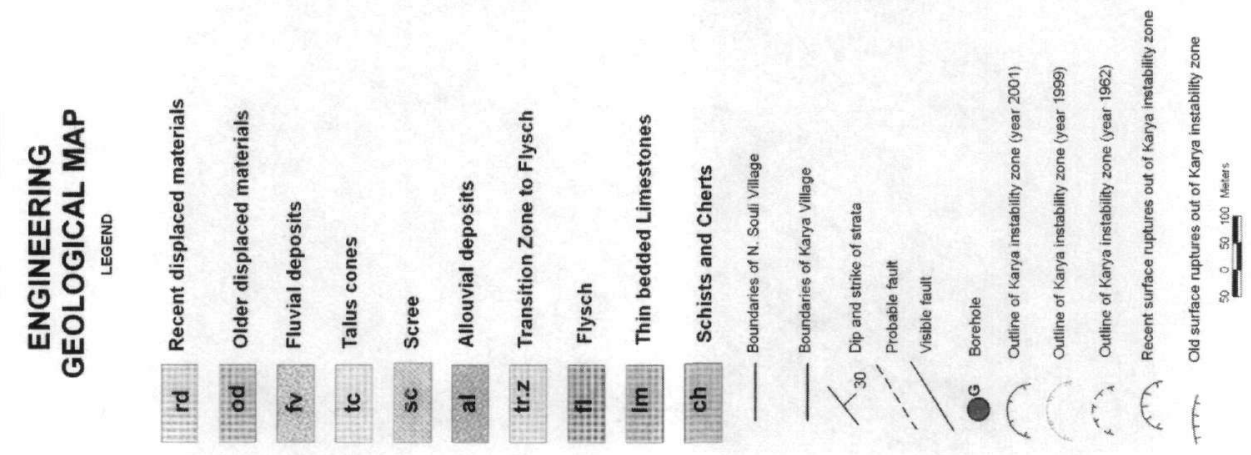

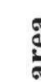

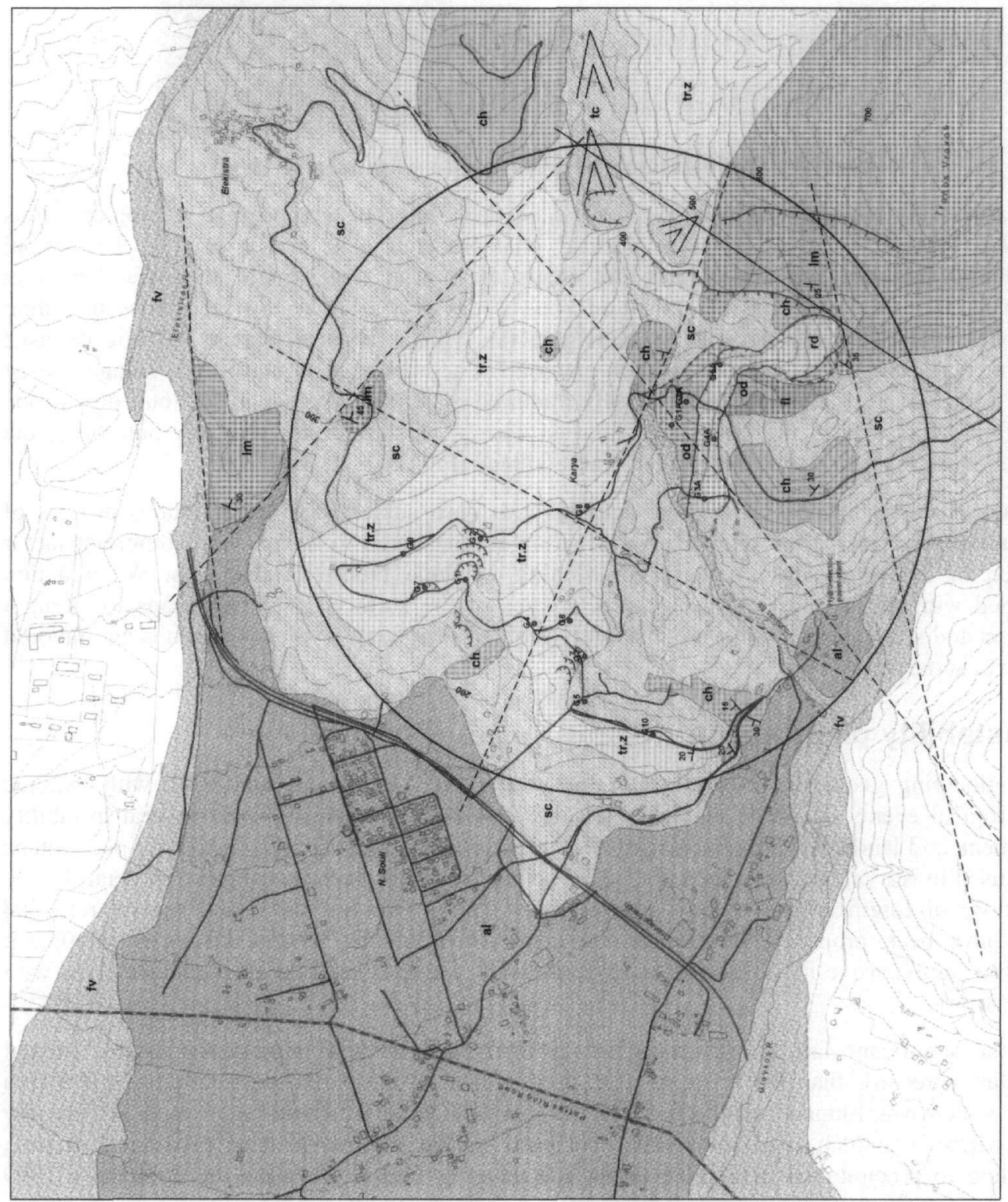

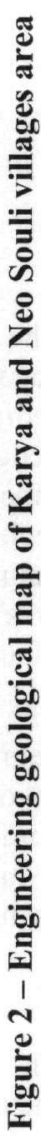


rainfall was $250 \%$ greater than the mean monthly value. The event was a debris flow followed by a translational multiple slide involving recent debris, older sliding materials and weathered zone of Flysch. The main road connecting nearby villages was destroyed, while the streamlet at the base of the gully was blocked by debris materials forming a 4-meter deep lake.

In December 2001, an intense rainfall of about $94 \mathrm{~mm}$ in less than 24 hours resulted to a sudden failure of a large volume of debris material that triggered a new extensive landslide. The debris flowed rapidly on the slope causing a "tongue" of saturated material to slip down and overtop the slope face. A translational slide was also activated in the lower part of the landslide. A newly constructed house founded inside older sliding materials was totally destroyed, while the main road connecting nearby villages was destroyed for a second time.

The 2001 event is the latest reactivation of the landslide. During and after the construction of the remedial works inclinometer tubes where installed inside the landslide body. Their role was to access the effectiveness of the remedial works and indicate a probable reactivation of the landslide. An almost two-year period of systematic measurement (June 2003 till March 2005) showed a continuous movement in the central part of the instability zone (borehole G2A), particularly at depths of 7 and $19 \mathrm{~m}$ with maximum displacement of about 7.5 and $3.6 \mathrm{~mm}$ respectively. Based on the inclinometer data it can be assumed that the landslide area has not been stabilized after the latest events. According to (Cruden and Varnes 1996) it can be classified as an landslide of an extremely slow rate of movement.

Apart from Karya landlide other regional sites of potential instability have been recognized inside the inhabited area, mainly across the road network that connects the two villages. In these sites the poor mechanical characteristics of sufrace materials, regional steep topography and absence of drainage systems have led to several small-scale instability problems and damages in some buildings.
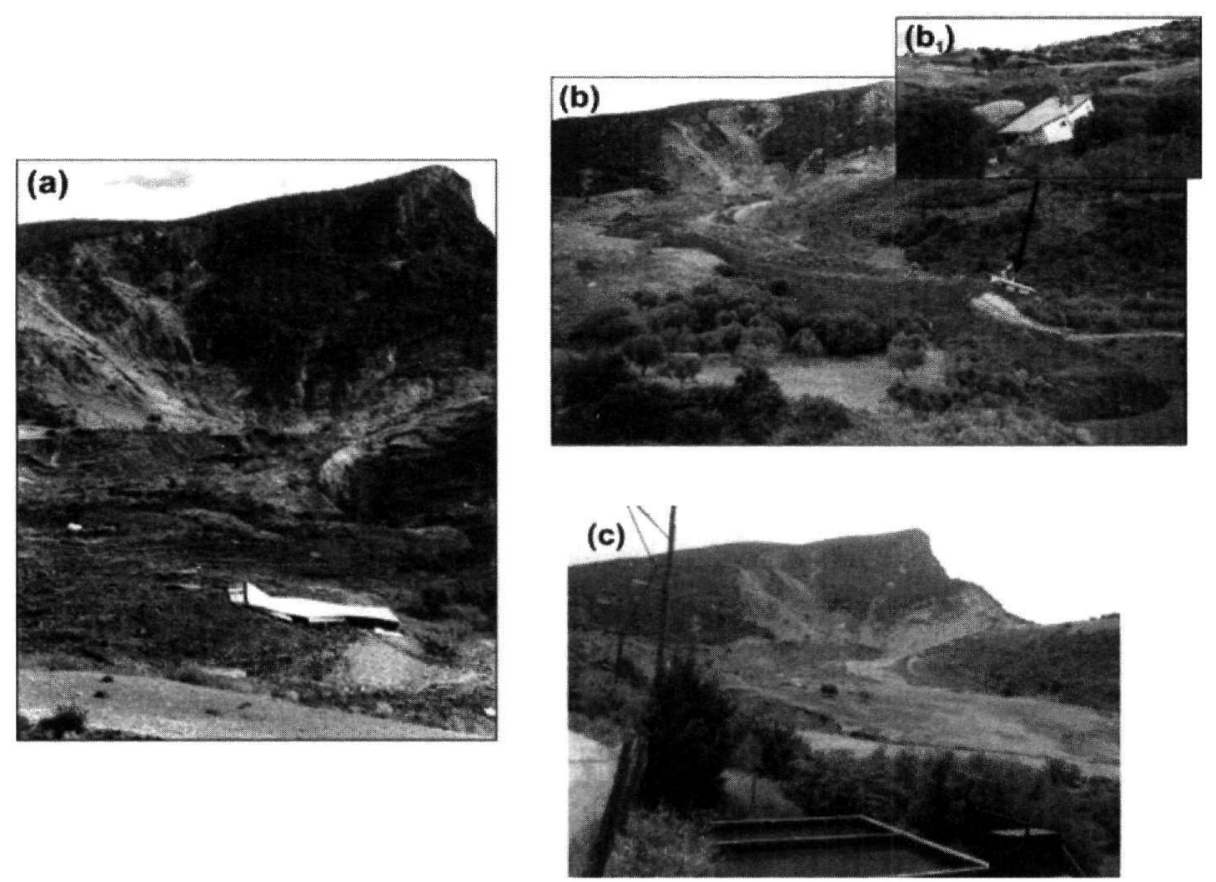

Figure 3 - Karya Landslide (a) 1999 event, (b) 2001 event (b $)_{1}$ damaged house and (c) current condition 


\section{Geotechnical appraisal}

\subsection{Soil classification}

Fifteen borings were drilled in order to identify the subsurface geology. Borings in Karya Landslide (G1A-G5A) were up to $51 \mathrm{~m}$ deep, while the drilling depth of those in the rest village area (G1 - G10) did not exceed 20m and stopped when bedrock was encountered. Standard Penetration Tests were executed in surfacial materials, while several soil and rock specimens were retrieved for laboratory testing.

The various soil and rock types where classified in three main Geotechnical Units according to their lithology and physical state (Table 1). In detail, the main Units I and II were further divided into several subunits according to their physical and mechanical behaviour. Table 2 and Table 3 show the general description, classification, thickness and measured range of physical and mechanical characteristics for these Units.

Table 1 - Main classification of soil and rock types

\begin{tabular}{|c|c|c|}
\hline Unit & & General Description \\
\hline I & \multicolumn{2}{|c|}{ Landslide materials, debris and weathered mantle } \\
\hline II & \multicolumn{2}{|c|}{ Intensely fractured and weathered complex materials of the transition zone } \\
\hline \multirow[t]{3}{*}{ III } & \multirow[t]{3}{*}{ Bedrock } & Flysch (IIIA) \\
\hline & & Limestones (IIIB) \\
\hline & & Schists - Cherts (IIIC) \\
\hline
\end{tabular}

Table 2 - Physical and mechanical characteristics for Geotechnical Unit I

\begin{tabular}{|c|c|c|c|c|}
\hline \multicolumn{5}{|c|}{ UNIT I } \\
\hline $\begin{array}{l}\text { Sub } \\
\text { Unit }\end{array}$ & & Decription & $\begin{array}{l}\text { Thickness } \\
\text { (m) }\end{array}$ & $\begin{array}{c}\text { Physical } \\
\text { Mechanical } \\
\text { characteristics }\end{array}$ \\
\hline IA & & Recent fills & $0-2$ & - \\
\hline IB & $\begin{array}{l}\text { Recent and } \\
\text { older } \\
\text { displaced } \\
\text { materials }\end{array}$ & $\begin{array}{l}\text { Greyish Brown Sandy Clay and } \\
\text { Clayey Sand }(\mathrm{CL}, \mathrm{SC}) \text { with } \\
\text { fragments } \\
\text { Clayey gravels with scattered } \\
\text { boulders (GM, GC) }\end{array}$ & $1-23$ & $\mathrm{~N}_{\mathrm{SPT}}: 10->50$ \\
\hline IC & $\begin{array}{l}\text { Sheared and } \\
\text { weathered } \\
\text { Flysch }\end{array}$ & $\begin{array}{l}\text { Grey Sandy Clay (CL) with } \\
\text { fragments }\end{array}$ & $1-7$ & $\begin{array}{l}\mathrm{N}_{\mathrm{SPT}}: 10-30 \\
\varphi_{\text {res }}=25^{\circ}\end{array}$ \\
\hline ID & $\begin{array}{l}\text { Scree and } \\
\text { weathered } \\
\text { mantle of } \\
\text { transition } \\
\text { zone }\end{array}$ & $\begin{array}{l}\text { Brownish Gray Sandy Clay- } \\
\text { Clayey Sand (CL, SC) with } \\
\text { angular gravels and intercalations } \\
\text { of Silty Sand (SM, ML) } \\
\text { Clayey and poorly-graded Gravel } \\
\text { (GC, GP-GC) }\end{array}$ & $1.50-14 \mathrm{~m}$ & $\begin{array}{l}\mathrm{N}_{\mathrm{SPT}}: 25-35 \\
\mathrm{w}: 13-17 \% \\
\gamma_{\mathrm{b}}: 19-22 \mathrm{kN} / \mathrm{m}^{3} \\
\mathrm{q}_{\mathrm{u}}: 120-360 \mathrm{kPa}\end{array}$ \\
\hline
\end{tabular}




\subsection{Geotechnical cross-sections}

In order to get a general and simpilified 2-D geotechnical model of the study area several geotechnical profiles and cross sections were drawn. Figure 4 illustrates the distribution of bedrock along with some representative Geotechnical cross section of the study area. As shown in Figure 4, in the north part of the study area Chert of Flysch bedrock is encountered in a depth between 10 and $15 \mathrm{~m}$ covered by relatively thick surfacial materials, whereas materials of Geotechnical Unit IIB dominate in the south part covered by a 7 -meter surfacial cover.

Table 3 - Physical and mechanical characteristics for Geotechnical Unit II

\begin{tabular}{|c|c|c|c|c|c|}
\hline \multicolumn{6}{|c|}{ UNIT II } \\
\hline \multirow[t]{2}{*}{$\begin{array}{l}\text { Sub } \\
\text { Unit }\end{array}$} & \multirow{2}{*}{\multicolumn{2}{|c|}{ Decription }} & \multirow[t]{2}{*}{$\begin{array}{l}\text { Thickness } \\
\text { (m) }\end{array}$} & \multicolumn{2}{|c|}{$\begin{array}{c}\text { Physical } \\
\text { Mechanical characteristics }\end{array}$} \\
\hline & & & & Group & Values \\
\hline IIA & \multicolumn{2}{|c|}{$\begin{array}{l}\text { Greyish Brown Sandy Clay (CL) with } \\
\text { gravels, cobbles and boulders and } \\
\text { intercalations of Silty Sand (SM, ML) } \\
\text { Clayey Gravel (GM, GC) }\end{array}$} & $0-3$ & - & $\mathrm{N}_{\mathrm{SPT}}: 15-20$ \\
\hline \multirow[t]{3}{*}{ IIB } & \multicolumn{2}{|c|}{$\begin{array}{l}\text { Mixed loose to moderately cemented } \\
\text { BRECCIA with brown and gray } \\
\text { Sandy-Clayey matrix }\end{array}$} & \multirow[t]{3}{*}{$\begin{array}{l}\text { Total } \\
\text { thickness up } \\
\text { to } 15 \mathrm{~m}\end{array}$} & $\begin{array}{l}\text { GP - } \\
\text { GM, GC, } \\
\text { GM-GC }\end{array}$ & $\mathrm{N}_{\mathrm{SPT}}:>50$ \\
\hline & \multirow{2}{*}{\multicolumn{2}{|c|}{$\begin{array}{l}\text { Sandy Clay (SC and CL), Sandy Silt } \\
\text { and well-graded Sand (SW-SM) }\end{array}$}} & & $\begin{array}{l}\mathrm{SC} \text { and } \\
\mathrm{CL}\end{array}$ & $\begin{array}{l}\mathrm{N}_{\mathrm{SPT}}: 20-28 \\
\mathrm{w}: 12-19 \% \\
\mathrm{\gamma}_{\mathrm{b}}: 20-22.5 \\
\mathrm{kN} / \mathrm{m}^{3} \\
\mathrm{q}_{\mathrm{u}}: 250-350 \mathrm{kPa}\end{array}$ \\
\hline & & & & SW-SM & $\mathrm{N}_{\mathrm{SPT}}:>50$ \\
\hline IIC & $\begin{array}{l}\text { Intensely } \\
\text { fractured and } \\
\text { weathered } \\
\text { cherts }\end{array}$ & $\begin{array}{l}\text { Brownish red Sandy } \\
\text { Clay (SC אal CL) } \\
\text { with angular gravels } \\
\text { Clayey Gravel (GM, } \\
\text { GC) } \\
\text { Intercalations of Silty } \\
\text { Sand (SM, ML) and } \\
\text { poorly-graded Clayey } \\
\text { Sand (SM, ML, SM - } \\
\text { SC, SP - SC). }\end{array}$ & $0-7$ & - & $\begin{array}{l}\mathrm{N}_{\text {SPT }}: 25-35 \\
\mathrm{w}: 15-24 \% \\
\gamma_{\mathrm{b}}: 20-21.5 \\
\mathrm{kN} / \mathrm{m}^{3} \\
\mathrm{q}_{\mathrm{u}}: 160-400 \mathrm{kPa}\end{array}$ \\
\hline IID & $\begin{array}{l}\text { Weathered } \\
\text { Flysch. }\end{array}$ & $\begin{array}{l}\text { Yellowish gray and } \\
\text { brown Sandy Clay } \\
\text { (SC) } \\
\text { Silt and Clay (ML, } \\
\text { CL - ML) with } \\
\text { angular gravels }\end{array}$ & $0-7$ & - & $\begin{array}{l}\mathrm{N}_{\mathrm{SPT}}: 25-45 \\
\mathrm{w}: 14-19 \% \\
\gamma_{\mathrm{b}}: 20.5-22.5 \\
\mathrm{kN} / \mathrm{m}^{3} \\
\mathrm{q}_{\mathrm{u}}: 160-450 \mathrm{kPa}\end{array}$ \\
\hline
\end{tabular}




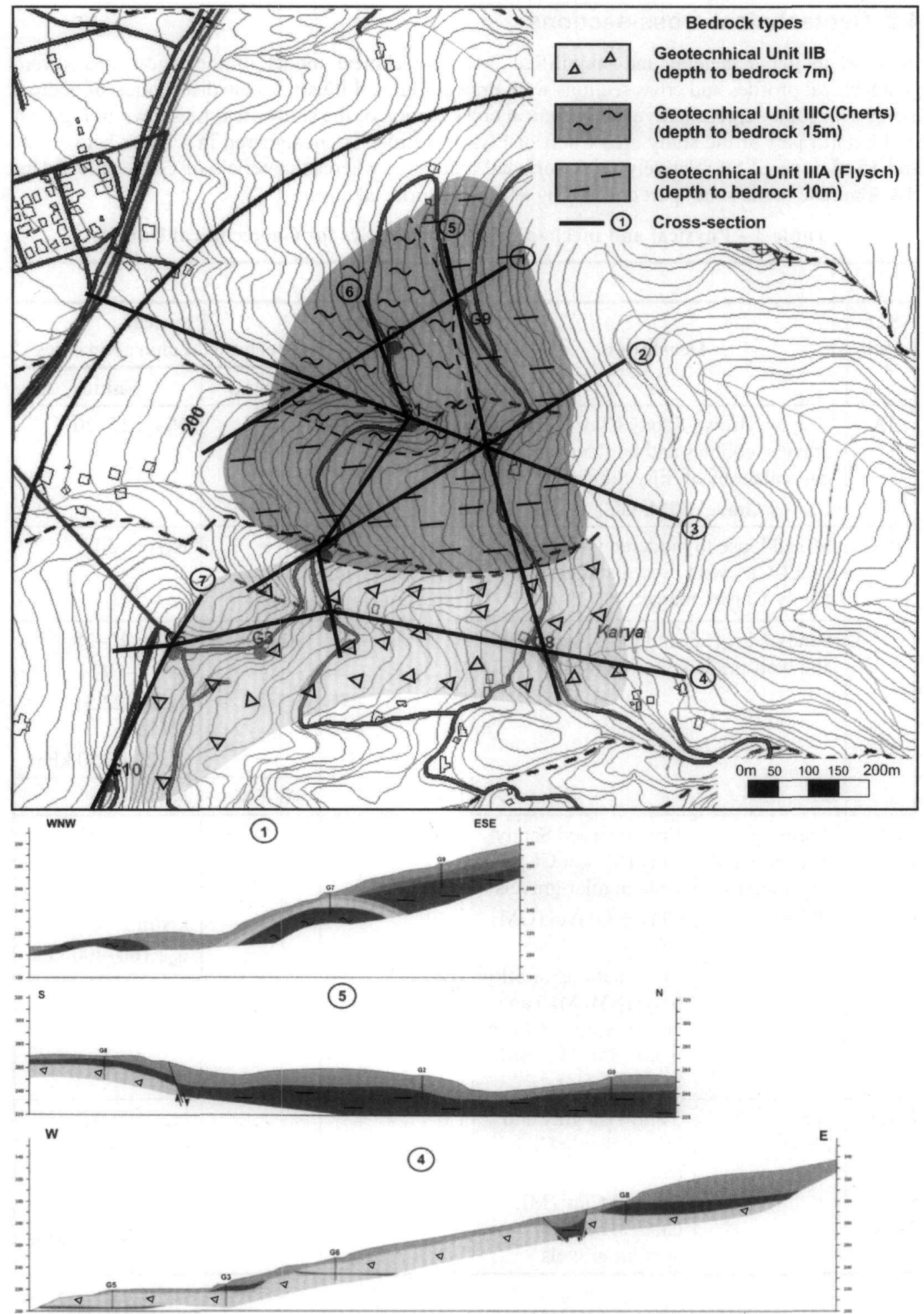

Figure 4 - Geotechnical cross-sections and distribution of bedrock types 


\subsection{Groundwater}

Water table depth measurements saw differential groundwater conditions between the north and the south part of the study area. Moderate to high water table (less than $10 \mathrm{~m}$ from sufrace) was measured in the north part sometimes near soil surface. On the other hand, the south part is characterized by low water table (more than $15 \mathrm{~m}$ from surface) or absence of water up to 20 meters (Fig. 5). The impermeable Flysch or Chert bedrock contributes to high water table conditions, whereas the intensely fractured and more permeable materials of Geotechnical Unit II are characterized by low water table or regional dry conditions.

\subsection{Slope stability analysis}

In order to investigate the critical instability conditions Limit Equilibrium slope stability analyses using the rigorous Morgenstern-Price method (Morgenstern and Price 1965) were established. The method satisfies all conditions of equilibrium and identifies the geometry of the most probable failure mechanism after computing the safety factor for various conditions of the radius and center of curvature of the sliding surface.

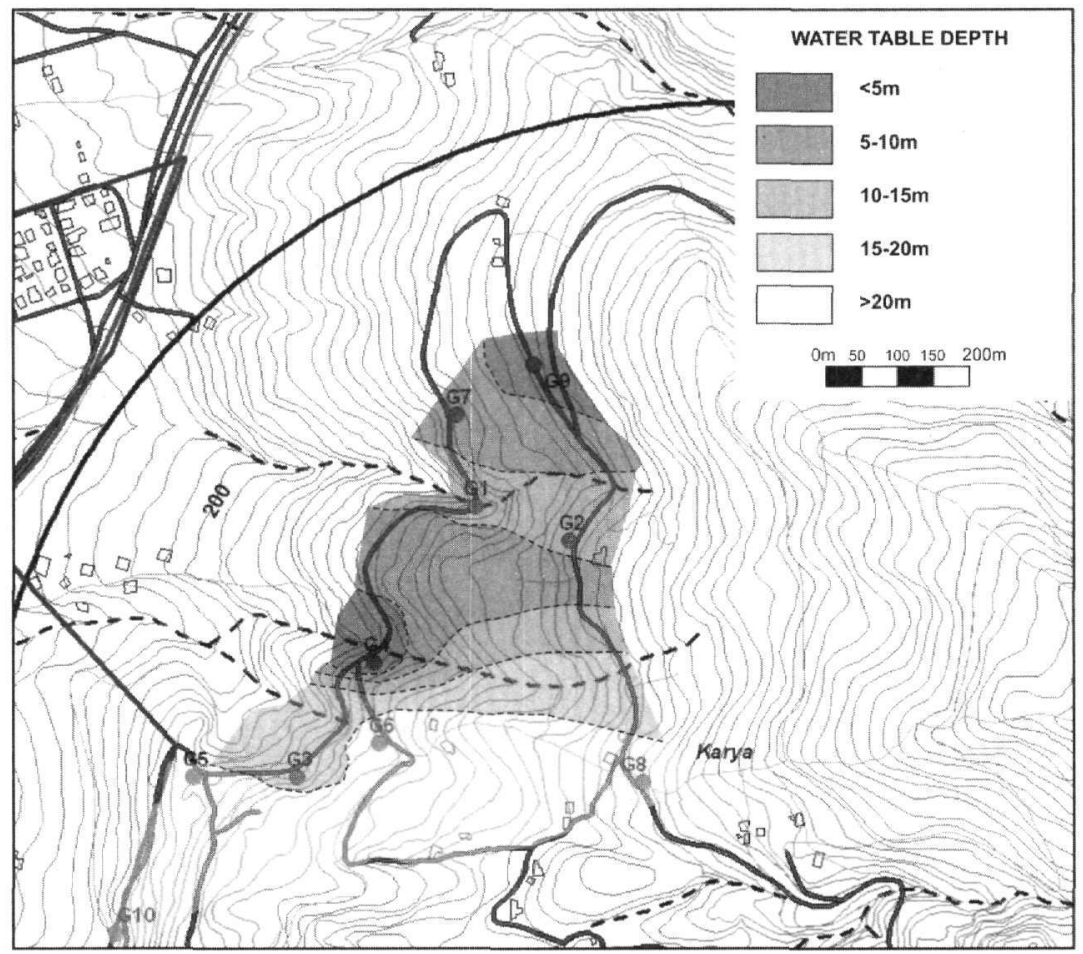

Figure 5-Water table depth distribution

The analyses were performed in several different cross sections. The geotechnical models of the slopes were simplified and mean values for geotechnical parameters estimated from laboratory and in situ tests were used (Table 4). Factor of Safety was calculated under four different cases regarding ground water conditions (Fig. 6). The worst scenario, representing a possible extreme meteorogical event (eg a heavy and prolonged rainfall) was simulated by assuming water table near ground sufrace combined with simple assumptions for the pore-water pressure ratio $(\mathrm{Ru})$. According to Krahn (2004) pore -water pressures based on Ru calculations can be added to conditions represented by a piezometric line. The Ru computed pore-water pressure will be added to the pore-water pressure computed from a piezometric line if the slice base is below the piezometric line and the slice base is in a soil with an assigned $\mathrm{Ru}$. Ground water table at surface was simulated by using single piezometric lines. 
Table 4 - Estimated geotechnical characteristics used in slope stability analyses

\begin{tabular}{|l|l|l|l|l|}
\hline \multicolumn{1}{|c|}{ Geotechnical Unit } & \multicolumn{1}{c|}{$\boldsymbol{\gamma}_{\mathbf{b}}\left(\mathbf{k N} / \mathbf{m}^{\mathbf{3}}\right)$} & $\mathbf{c}(\mathbf{k P a})$ & \multicolumn{1}{c|}{$\boldsymbol{\varphi}^{\mathbf{0}}$} & \multicolumn{1}{c|}{$\mathbf{R u}$} \\
\hline ID & 19 & 60 & 25 & 0.5 \\
\hline IIA & 19 & 50 & 20 & 0.5 \\
\hline IIB & 22.5 & 70 & 30 & 0.2 \\
\hline IIC & 20 & 60 & 20 & 0.5 \\
\hline IID & 20 & 50 & 25 & 0.4 \\
\hline III (Bedrock unified) & 23 & 250 & 27 & - \\
\hline
\end{tabular}

As shown in Figure 6, low Safety Factor values were computed in the north part of the area so, according to the results, it is more susceptible than the rest region for instability problems under extremely high pore-water pressure conditions, caused by heavy and prolonged rainfalls.

\begin{tabular}{|c|c|c|c|c|c|}
\hline \multirow[b]{2}{*}{$\begin{array}{c}\text { Cross } \\
\text { section }\end{array}$} & \multirow[b]{2}{*}{$\begin{array}{l}\text { average } \\
\text { slope } \\
\text { gradient } \\
\text { (degrees) }\end{array}$} & \multicolumn{4}{|c|}{ Ground wvater conditions } \\
\hline & & $\begin{array}{c}\text { Dry } \\
\text { conditions }\end{array}$ & $\begin{array}{l}\text { water table } \\
\text { at surlace }\end{array}$ & ru & $\begin{array}{c}\text { combination } \\
\text { of water table } \\
\text { at surface } \\
\text { und ru }\end{array}$ \\
\hline G1-G2 & 20 & 2.35 & 1.65 & 1.56 & 085 \\
\hline \multirow{2}{*}{ G7-G9 } & Between G7-G9: 17 & - & - & - & 1.08 \\
\hline & Downhill G7 : 20 & 2.32 & 1.87 & 1.62 & 1.14 \\
\hline G4 & 15 & 2.71 & 1.86 & 1.79 & 0.93 \\
\hline \multirow{2}{*}{ G3 } & Uphill G3 : 15 & \multirow{2}{*}{1.93} & \multirow{2}{*}{-} & \multirow{2}{*}{1.48} & \multirow{2}{*}{-} \\
\hline & Downhill G3 : 20 & & & & \\
\hline \multirow[t]{2}{*}{ G6 } & Uphill G6 : 20 & \multirow{2}{*}{2.50} & \multirow{2}{*}{ - } & \multirow{2}{*}{2.12} & \multirow{2}{*}{ - } \\
\hline & Downhill G6 : 10 & & & & \\
\hline G5 & 20 & 3.10 & 一 & 2.52 & - \\
\hline \multirow{2}{*}{ G10 } & Uphill G10 : 30 & \multirow{2}{*}{2.05} & \multirow{2}{*}{-} & \multirow{2}{*}{1.72} & \multirow{2}{*}{ - } \\
\hline & Downhill G10: 10 & & & & \\
\hline G8 & 10 & 2.69 & - & 1.87 & - \\
\hline
\end{tabular}

(a)

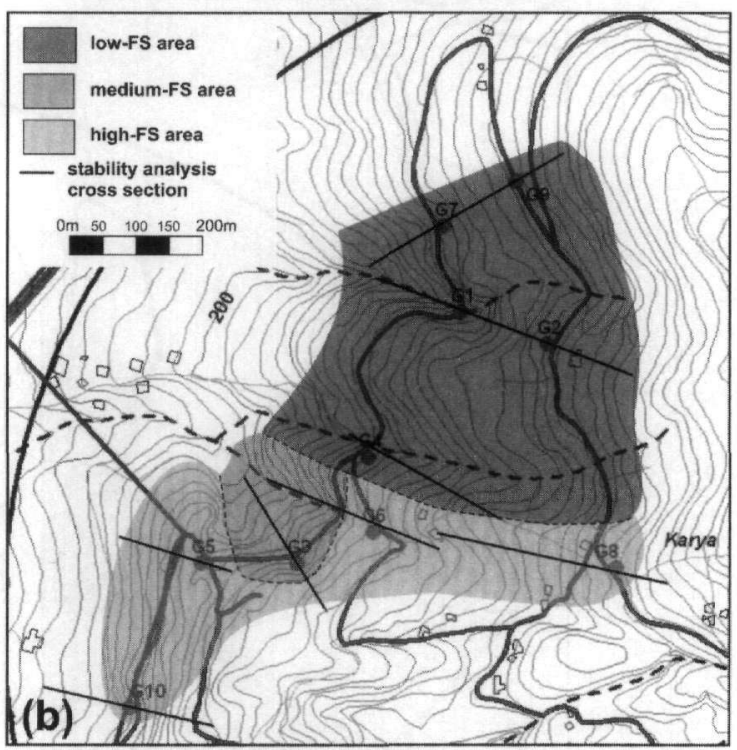

Figure 6 - (a) Slope stability analyses results (b) distribution of estimated Safety Factors

\section{Results - Soil suitability division}

Based on the engineering geological and geotechnical investigation the village area was finally divided into five zones according to the encountered ground for housing purposes (Fig. 7):

- Zone 1 was classified as suitable for housing since it is relative flat, it consists of stiff recent Pleistocene-Holocene deposits and has not instability problems.

- Zone 2 consists of coarse grained Unit IIB materials covered by up to $5 \mathrm{~m}$-thick scree and weathered materials. It is characterized by low water table, absence of instability problems and has relatively high Safety Factor values according to slope stability analyses.

- Zone 3 consists of weathered Chert bedrock covered by about 4-meter thick surfacial materials and 11-meter thick various intensely fractured materials of Unit II. It is characterized by high water table, small-scale instability problems and lower Safety Factor values according to slope stability analyses. 
- Zone 4 consists of weathered Flysch bedrock covered by up to 12-meter thick surfacial scree materials. It is characterized by high water table, small-scale instability problems and has the lower Safety Factor values according to slope stability analyses.

- Zone 5 represents soil formations and engineering geological conditions unsuitable for housing, due to active Karya landslide inside it.

Several housing requirements and suggestive guidelines for housing were specified for Zones 3, 4 and 5 regarding foundation, excavation and drainage. Zone 4 was considered as the worst among them for housing. Specified requirements and guidelines aim to prevent from instability phenomena caused by static loading, ground water conditions or excavation. The general guidelines suggest:

- Avoidance of surfacial fine-grained soils of Unit ID as foundation materials

- Avoidance of mechanical excavation in slopes with inclinations exceeding $35 \%$. For slopes inclined less than $35 \%$, a $3 \mathrm{~m}$ maximum height of excavation is suggested supported with retaining walls.

- Surface water runoff with net of diversion ditches.

- Construction of interceptor drains parallel to the road sides.

- Protection and preservation of streamlets' flow zones.

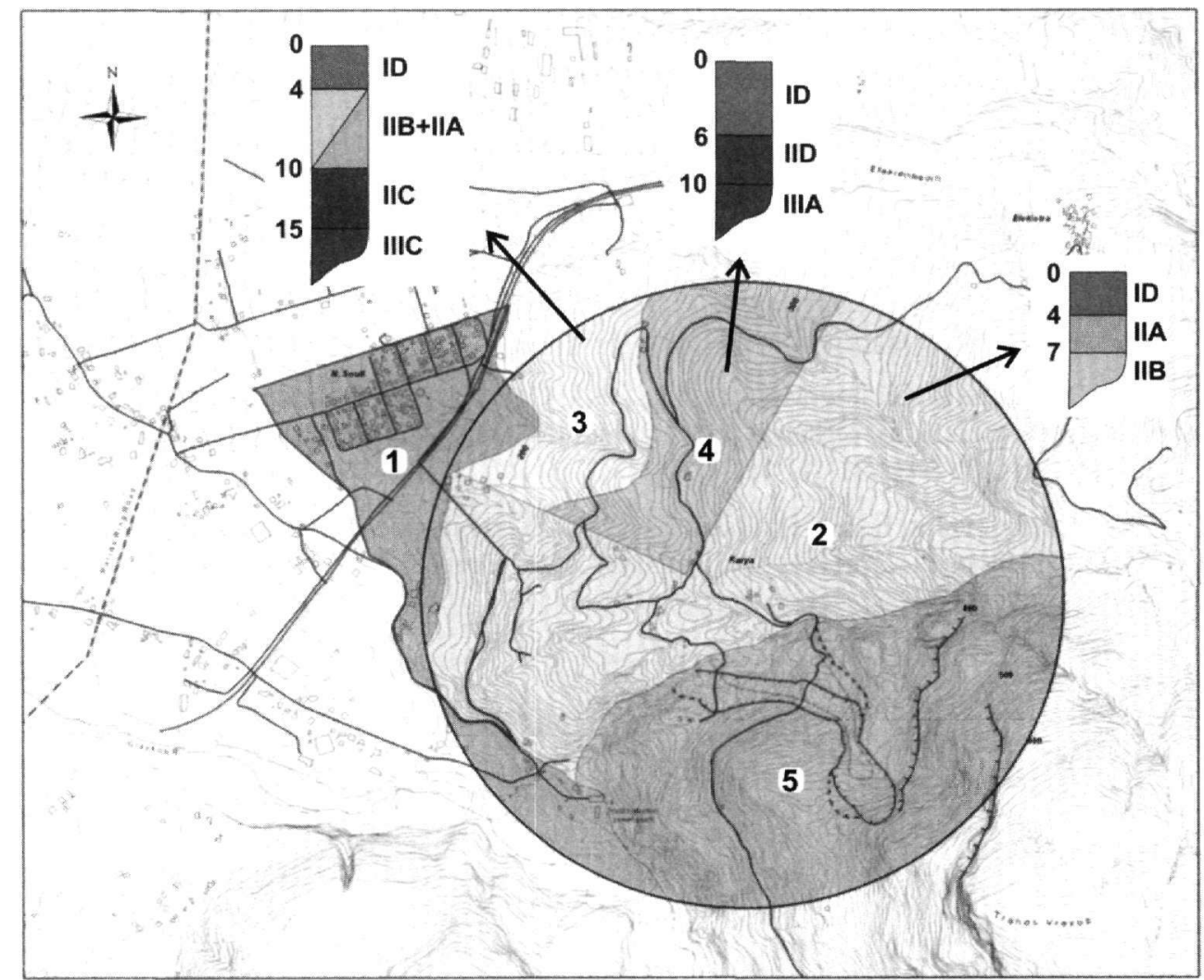

Figure 7 - Soil suitability division in village area and typical geotechnical columns of the three zones to which housing requirements were specified 


\section{Acknowledgments}

This work was carried out under the support of the Local Authorities of Achaia Prefecture. The authors wish to express their sincere appreciation to their generous support.

\section{References}

Cruden, D., and Varnes, D., 1996. Landslide Types and Processes, In A. Turner and R. Schuster (ed.), Landslides: Investigation and Mitigation, Transportation Research Board, National Research Council, 247, 36-75.

Doutsos, T., and Kokkalas, S., 2001. Stress and deformation pattern in the Aegean region, J Struct Geol 23, 455-472.

Ferentinos, G., Brooks, M., and Doutsos, T., 1985. Quaternary tectonics in the Gulf of Patras, western Greece, J Struct Geol, 7/6, 713-717.

Koukis, G., Tsiambaos, G., and Sabatakakis, N., 1996. Landslides in Greece: Research evolution and quantitative analysis, Landslides, Senneset(ed), Balkema, Rotterdam, 1935-1940.

Koukis, G., 2005. Geotechnical Survey in Karya and Neo Souli Villages, University of Patras, Department of Geology, Laboratory of Engineering Geology. (in Greek)

Koukis, G., 2003. Monitoring and Mapping of Karya Landslide, University of Patras, Department of Geology, Laboratory of Engineering Geology. (in Greek)

Koukouvelas, I., and Doutsos, T., 1996. Implications of structural segmentation during earthquakes: The 1995 Aigion earthquake, Gulf of Corinth, Greece, J Struct Geol, 18, 13811388 .

Morgenstern, N.R., and Price, V.E., 1965. The Analysis of the Stability of General Slip Surfaces, Geotechnique, 15, 79-93.

Krahn John, 2004. Stability Modelling with SLOPE/W, An Engineering Methodology. GeoSlope International Ltd, First Edition, 394pp.

Sabatakakis, N., Koukis, G., and Mourtas, D., 2005. Composite slides induced by heavy rainfalls in suburban areas: City of Patras and surrounding area, Western Greece, Landslides, 2, 202211.

Zelilidis, A., Koukouvelas, I., and Doutsos, T., 1988. Neogene paleostress changes behind the fore arc fold belt in the Partakes Gulf area, western Greece, N. Jb. Geol. Palaont. Mh, H.5, Stuttgart, 311-325. 